\title{
Assessing the Impact of Relational Governance on the Supply Chain Performances of Manufacturing Firms in Ghana
}

\author{
Chris Jojo Obi* Xiong Qiang Courage Simon Kofi Dogbe Wisdom Wise Kwabla Pomegbe \\ School of Management, Jiangsu University, P.R. China \\ *E-mail of the corresponding author: 5102170219@stmail.ujs.edu.cn
}

\begin{abstract}
Over the years, there have been many challenges in supply chain management across the globe especially in the developing countries. There were challenges of quality control, risk management, finding right distributors to handle distribution, fragmented markets and many others. The most challenging issue in the supply chain management is the unpleasant relationship between the firms and their partners leading to many inconsistencies, uncertainties and losses in their operations and transactions leading to the assessment of both the direct and indirect impact of relational governance on supply chain performance of the manufacturing firms in Ghana. The study sought to assess the impact relational governance has directly and indirectly on supply chain performance. Data were collected and gathered through a survey questionnaire responded by 147 manufacturing firms in Ghana. The structural equation modelling was used to test the hypothesis and also validate the results. Findings indicate that the relational governance has a positive effect on supply chain performance and at the same time has an indirect effect on supply chain performance through both information sharing and quality of information. The study provides a hard evidence that the higher levels of information sharing and quality of information can lead to enhanced effect of relational governance on supply chain performance.
\end{abstract}

Keywords - Relational Governance, Information Sharing, Quality of Information, Supply Chain Performance, Manufacturing Firms.

DOI: $10.7176 / \mathrm{EJBM} / 12-12-01$

Publication date: April $30^{\text {th }} 2020$

\subsection{Introduction}

Nowadays supply chain has become momentous method for firms to enhance their profitability and remain competitive (Li 2006). This has led to studies that focused on certain facets of the field of supply chain management which includes among others, suppliers selection (Inemek 2009, Igarashi 2013), manufacturers and retailers connections (Li 2005), supply chain resilience (Carvalho 2014), supply chain management Practice (Li 2005, Li 2006, Zimmermann 2014), sustainable and green supply chain (Kumar 2015, Choi 2016)

Supply Chain Management is regarded as the integration of all activities associated with the flow and transformation of goods from the raw material stage, through to the end user, as well as the associated information flows through improved inter-and intrafirm relationships to achieve sustainable competitive advantage (Ellinger 2000). The practice of supply chain management meets the essential requirement which makes a firm to survive in the competitive global race and also yield profit (Moberg 2002).

Supply chain performance is measured by the ability to satisfy the ultimate customer in terms of both quality and cost (Chen 2004). The success of an organization first depends upon the performance of the supply chains in which the organization forms a partner (Rosenzweig 2003). Supply chain performance also rely on the abilities of the supply chain partners to adapt to the dynamism of the environment (Vanderhaeghe 2003). The effectiveness of supply chain management which improves supply chain performance depends on a long-term cooperative relationship with a low number of suppliers who can supply high-quality products or services (Kaynak 2003).

Many supply chain management efforts have failed to achieve the desired results. One of the major supply chain challenges facing manufacturing firms in developing countries such as Ghana from various research studies are their exclusively suppressed and unpleasant relationships with their partners or suppliers. This mostly prohibit the firms to create opportunities for improvement in terms of supply chain performance and the performance of the firms as a whole.

Relational governance has become very complicated over the past couple of years, several scholars have made more emphases on the importance of attending to the dynamic transnational networks of public, private and nonprofit organizations. Over time, relational governance have frequently changed (Ness 2009). Relational governance can be considered to be a single, higher-order construct in a second-order factor model where the firstorder factors are a set of highly correlated relational norms (Cannon 1999).

The context of the exchange can have an effect on the relative importance of a given relational norm with respect to its performance (Paulin 1999). They have also shown some positive effects of relational governance practices on supply chain performance of firms and overall firms' performance improvement. The relational governance can promote the willingness to adapt flexibly under conditions of uncertainty (Bradach 1989). Several literatures under this study provides trust, flexibility, information exchange and commitment as the most essential 
relational elements (Heide 1994, Cullen 2000, Poppo 2002, Griffith 2005, Cao 2015). All these relational elements come together with sufficient strength to curb opportunism. Relational governance also show their roles in an enduring relationships (Hewett 2001), the continuity of relationships depend on the values involving benefits and costs comparison of the current relationship. The examination of appropriate governance mechanisms has brought about an increase in relationship quality, develop inter-firm learning and create relationship value (Ying-Pin Yeh 2016).

To attain a certain high level of quality in supply chain, a certain stable and lasting relationships that causes the suppliers to make the investment required for customer satisfaction needs to be developed (Cannon 2010). Where trust acting as relational variable serves as a mechanism which facilitates cooperation and generate relationship commitment (Morgan 1994) and commitment as a relational norm is the continuous need to preserve a relationship (Moorman 1992). Quality of information as one of the supply chain management practices include facets such as timeliness, accuracy, adequacy and credibility of information exchanged (Li 2006). Quality of information plays a key role in a making supply chain management effective which also influences the supply chain performance of a firm. Level of information sharing as a supply chain practice dimensions is being defined as the communication of critical information among supply chain partners involved in a particular supply chain (Li 2006).

Various studies have been conducted in various sectors such as pharmaceutical (Papalexi 2016), agriculture (Dani 2010), telecommunication (Reyes 2002), automobile (Blos 2009 ), construction (Saad 2002), chemical (Foerstl 2010). Notwithstanding this, there is less research studies on the supply chain management in affiliation with the practices that manufacturing firms in developing countries like Ghana need to embrace to make their supply chain a sturdy competitive tool for their growth. The geographical, political and economic components of Ghana as well as its current situation of broadening the manufacturing industry and a possible entry to West Africa makes the supply chain of its manufacturing industry distinctive from other studies conducted. The economy of Ghana is overshadowed by manufacturing SMEs and with limitation but the struggles in maintaining relationships between the firms and their partners in the supply chain makes it uncommon situation that requires further examination.

The study therefore sought to conceptually test a framework which seeks to assess the impact relational governance has directly and indirectly on supply chain performance. This study is conducted in the Ghanaian manufacturing industry in relation to the relational governance and its effect on the supply chain and firms performance among the firms.

\subsection{Theoretical and Literature Review}

Relational governance refers to that kind of governance in which the parties ${ }^{\text {ee }}$ personal relations become heavily intertwined with the economic exchange (Gil 2009). These personal relations refer to social norms such as trust, cooperation and solidarity, amongst others. In these relationally-governed exchanges, obligations, pledges and expectations are enforced through the promotion of noneconomic, sociological norms such as flexibility, solidarity and information exchange (Poppo 2002). Ensuring the quality of shared information plays a key role in achieving effective SCM (Li 2006), organizations should ensure that it flows with minimum delay and distortion (Li 2006). The importance of quality of information sharing has been given attention in the academic literature in relation to its effect on SCM (Li 2006, Li 2006). Information Sharing (IS) means the distribution of critical and proprietary information to supply chain partners ( $\mathrm{Li} 2005$ ). The main barriers that organizations encounter in upgrading information sharing capabilities include information privacy, incentive issues, reliability, cost and complexity of technology, timeless, accuracy and effective utilization of information (Zhao 2002, Fawcett 2007).

SCP has been defined by (Banomyong 2011) as "the efficiency which takes into account multiple performance measures related to supply chain members, as well as the integration and coordination of members' performance". (Stevens 1990) suggests SCP measurement in terms of service level, cost, throughput efficiency, and inventory level and supplier performance.

\subsection{Conceptual Framework}

Figure 1.shows the empirical framework of the study. The framework depicted by the rationale that a higher level of the level and quality of information leads to higher level of supply chain performance and enhances firms' performance. The framework proposes that relational governance has a direct effect on supply chain performance and also has an indirect effect on supply chain performance through the level of information sharing and also the quality of information. Both the level of information and the quality of information acts as mediators for relational governance and the supply chain performance, the relational governance is independent variable while the supply chain performance is a dependent variable as shown in Figure 1. 


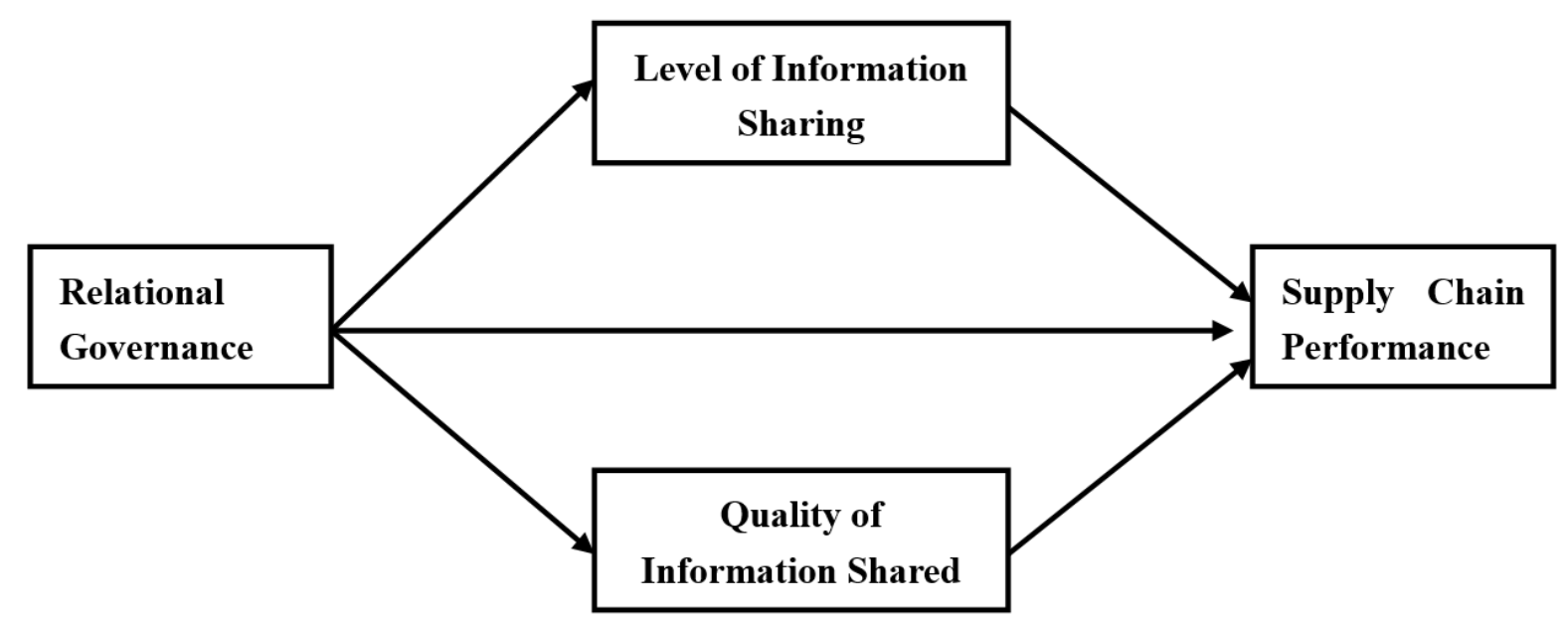

Figure 1: Hypothesized Model

\subsection{Relational Governance and Supply Chain Performance}

Improving supply chain performance demands that supply chain partners such as subcontractors or suppliers adopt a common processes of resolving exchange challenges. Relational governance as one of the governance mechanisms that tend to resolve exchange problems among partners, has been found to resolve exchange problems and also enhance performance (Cheng et al., 2014; Heide and John, 1988). According to Macneil, (1980), relational governance is a contract to a relationship among parties that is embedded in share norms and values. Trust is fundamental in relational governance. Relational governance mechanism is again stated to enhance parties' collaborative efforts or performance with less monitoring and bargaining (Zhang et al., 2009; Barney and Hansem, 1994). Ferguson et al. (2005) suggested that relational governance enhances exchange performance. Studies (such as, Zhang et al., 2009; Ferguson et al., 2005; Dolci et al., 2017) have established the positive influence of relational governance on exchange performances. For instance, Dolci et al. (2017) also found that relational governance has a positive effect on both operational and financial supply chain performance. Based on the aforementioned discussion, we hypothesize that;

H1: Relational governance has a direct relationship with and supply chain performance

\subsection{The Mediating Role of Level of Information Sharing}

When relational control exist, there is an establishment of trust among the partners and excessive flow of relevant information among the firms. There is a positive impact of the sharing of information on inventory depletion and reduction of cost (Zhao 2002). Two dimensions of Information sharing namely the comparability and the readiness which were both discovered to affect supply chain performance (Fawcett 2007). Information sharing has a considerable effect on the total cost of running a successful supply chain, and improves the holistic management of supply chain activities. Rashed (2010) have utilized the impact of both information and knowledge on suppliers' operational performance. Beside the trust and devotions among the firms which can directly improve the supply chain performance, the existence of the level of information sharing can improve the impact trust and devotions have on supply chain performance. The higher the level of information sharing among the firms, the more the trust and commitment level of the firms grows which in both short and long term affect the supply chain performance of the firms. Relational governance has a direct impact on level of information sharing while the level of information sharing also has a direct impact on supply chain performance. There is an indirect relationship between relational governance and the supply chain since the effectiveness of supply chain performance is determined by the level of information sharing (Pomegbe et al., 2019).

H2: The level of information sharing acts as a mediator between relational governance and supply chain performance

\subsection{The Mediating Role of Quality of Information}

Relational governance in a long term builds trust and commitment among firms, unlike traditional approaches to business relationships that rely heavily on authority and commit to correlate the inter-organizational activities (Weitz 1995), making relational governance more solid and efficacious in the B2B markets (Claro 2003). Quality information seeks to meet functional, technical, cognitive, aesthetic requirement of information producers, administrators, consumers and experts. The existence of long term trust and commitment cause the flow of quality information among inter-firms. There has been a confirmation that when quality information is kept, better supply chain performance is achieved. The firms must link supply chain practices with the quality of information in order to enhance the overall business performance (Zhou et al. 2014). The quality of information which circulates among 
the firms affects the trust and commitment of the various firms' growth which also affects the performance of supply chain in the long-term (Pomegbe et al., 2019). Relational governance has a direct impact on level of information quality while the information quality also has a direct impact on supply chain performance. There is therefore an indirect relationship between relational governance and the supply chain since the effectiveness of supply chain performance is determined by the quality of information.

H3: Quality of information acts as a mediator between relational governance and supply chain performance.

\subsection{Method}

The study targeted the respondents who have knowledge and experience on the supply chain operations and managements of the organizations. The CEOs, Managing Directors, logistics managers, purchasing managers, supplying managers, operations managers and planning managers were consulted as the main source of information. These managers were also appealed to refer to their major suppliers and customers when tackling those significant questions. This study also involved a total of 200 organizations from the manufacturing industries such as the food processing, beverage and breweries companies, furniture, paper and packaging, textile, chemical rubber products, electrical equipment and automobile, plastics. All these firms contacted have been doing business for at least five (5) years and have a minimum of about fifty (50) employees.

In addition, a carefully designed research questionnaire were administered as the main data collection instrument whilst tabulation, graphs were the main analytical tool. These sources of information were gotten from academic journals, reports, articles, papers which were presented at conferences and books. Information were also obtained from the World Wide Web using the Google search engine. Subsequently an in-depth study was carried out in order to analyze the benefits of regional manufacturing plants for fast moving consumer goods firms. Email was considered to be the most effective method of distributing the questionnaires. This strategy of distribution has some significance that involves quicker distribution, more professional and also lower cost. These significance identified in the above distribution strategy adds to the increase in the responsive rate.

\subsection{Firm Characteristics}

Table 1 shows the background information of the manufacturing firms selected for the study. The firms' ears of operation (age) and the size of the firm. The analysis presented shows that 29(19.7\%) firms have existed between the years of 5 and 10 . In other words, the $29(19.7 \%)$ firms have been in operation for a maximum of 5 years. There were $64(43.5 \%)$ firms that have been in operation or existence for 11 to 15 years. There were $38(25.9 \%)$ firms that have existed or operated for 15-20 years and there were $16(10.9 \%)$ firms that have existed for more than 20 years. The analysis on size of the firms presented indicate that $32(21.8 \%)$ firms have less than 50 employees. There were $66(44.9 \%)$ firms that have 50 to 100 employees. There were $49(33.3 \%)$ firms that have more than 100 employees.

Table 1: Firm Characteristics

\begin{tabular}{llll}
\hline Characteristics & Responses & Frequency (N) & Percentage (\%) \\
\hline Age & 5-10 years & 29 & 19.7 \\
& 11-15 years & 64 & 43.5 \\
& 15-20 years & 38 & 25.9 \\
& Above 20 years & 16 & 10.9 \\
Size & Total & $\mathbf{1 4 7}$ & $\mathbf{1 0 0 . 0}$ \\
& Less than 50 employees & 32 & 21.8 \\
& 50-100 employees & 66 & 44.9 \\
& More than 100 employees & 49 & 33.3 \\
& Total & $\mathbf{1 4 7}$ & $\mathbf{1 0 0 . 0}$ \\
\hline
\end{tabular}

\subsection{Survey Questionnaires and Measures}

The conceptual framework shows the observed items which were used in measuring the variables in the framework of the study. There were four (4) variables indicated in the framework of this study. These variables are relational governance which acts as an independent variable, the level of information which acts as a mediator, the quality of information which acts as a mediator too and the supply chain performance which acts as dependent variable. In this study all the measures beneath relational governance, the respondents responded on Likert Scale of 1 strongly disagree to 5 strongly agree which was indicated on the questionnaire by the researcher. Relational governance had 11 observed variables. The level of information had 6 variables and none of the variables were deleted to poor factor loading. The quality of information had 5 variables. The supply chain performance had 8 measurement variables. The measurement items for relational governance were adapted from Ferguson et al. (2005), whiles the measurement items of level of information sharing, quality of information, and supply chain performance were adapted from Al-Shboul et al. (2017). 


\subsection{Data Analysis}

The variables of the various constraints recorded both the standardized factor loadings, unstandardized factor loading, Standard Error, Critical Ratio. In the confirmatory factor analysis the Relational Governance recorded a Cronbach Alpha of 0.955 which is at least 0.7 and above indicates that there is a high reliability in the relational governance. The level of information sharing also recorded a Cronbach Alpha of 0.850 which is at least 0.7 and above indicates that there is also a high reliability in the level of information sharing. The quality of information recorded a Cronbach alpha of 0.881 which is at least 0.7 and above indicates that there is a high reliability in the quality of information. The supply chain performance also recorded 0.925 which is at least 0.7 and more indicates that there is also a high reliability in the supply chain performance. In the model fits, the CMIN is statistically insignificant at 5\%. The CMIN/DF is 1.893 which is less than 3. The GFI is 0.876 which is supposed to be greater than 0.8 . P close recorded a figure of 0.060 which is also more than 0.05 . The TLI and CFI recorded figures of 0.964 and 0.927 respectively which are both expected to be greater than 0.9. The RMSEA and S/RMR recorded figures of 0.047 and 0.038 respectively which are both expected to be less than 0.08 . The critical ratio is highly significant at $1 \%$ since it recorded a figure more than 2.53

Table 2: Confirmatory Factor Analysis (CFA)

\begin{tabular}{|c|c|c|c|c|}
\hline $\begin{array}{l}\text { Measurement } \\
\text { Items }\end{array}$ & Std. Factor Loadings & Undstd. Factor Loadings & S. E. & C. R. \\
\hline \multicolumn{5}{|c|}{ Relational Governance (ReG): CA $=\mathbf{0 . 9 5 5}$} \\
\hline RG1 & .800 & 1.201 & .098 & $12.275^{* *}$ \\
\hline RG2 & .842 & 1.203 & .089 & $13.519^{* *}$ \\
\hline RG3 & .828 & 1.093 & .084 & $13.072^{* *}$ \\
\hline RG4 & .748 & .923 & .084 & $10.935^{* *}$ \\
\hline RG5 & .787 & .975 & .083 & $11.802^{* *}$ \\
\hline RG6 & .742 & .876 & .081 & $10.825^{* *}$ \\
\hline RG7 & .732 & .828 & .078 & $10.642^{* *}$ \\
\hline RG8 & .806 & .979 & .079 & $12.443^{* *}$ \\
\hline RG9 & .863 & 1.090 & .063 & $17.226^{* *}$ \\
\hline RG10 & .893 & 1.230 & .063 & $19.676^{* *}$ \\
\hline RG11 & .862 & 1.000 & & \\
\hline \multicolumn{5}{|c|}{ Level of Information (LoI): CA $=\mathbf{0 . 8 5 0}$} \\
\hline LI1 & .721 & 1.000 & & \\
\hline LI2 & .771 & 1.000 & .132 & $7.592^{* *}$ \\
\hline LI3 & .779 & 1.001 & .134 & $7.474^{* *}$ \\
\hline LI4 & .793 & 1.073 & .123 & $8.749^{* *}$ \\
\hline LI5 & .742 & 1.092 & .148 & $7.393^{* *}$ \\
\hline LI6 & .888 & 1.098 & .219 & $5.003^{* *}$ \\
\hline \multicolumn{5}{|c|}{ Quality of Information (QoI): CA = .881 } \\
\hline QI1 & .866 & 1.034 & .198 & $5.234^{* *}$ \\
\hline QI2 & .879 & 1.014 & .209 & $4.857^{* *}$ \\
\hline QI3 & .774 & .9751 & .146 & $6.695^{* *}$ \\
\hline QI4 & .915 & 1.214 & .256 & $4.734^{* *}$ \\
\hline QI5 & .792 & 1.000 & & \\
\hline \multicolumn{5}{|c|}{ Supply Chain Performance (SCP): $\mathbf{C A}=\mathbf{0 . 9 2 5}$} \\
\hline $\mathrm{SC1}$ & .731 & 1.000 & & \\
\hline $\mathrm{SC} 2$ & .778 & 1.173 & .108 & $10.852^{* *}$ \\
\hline $\mathrm{SC} 3$ & .689 & 1.080 & .130 & $8.278^{* *}$ \\
\hline $\mathrm{SC} 4$ & .873 & 1.280 & .119 & $10.730^{* *}$ \\
\hline SC5 & .883 & 1.305 & .120 & $10.855^{* *}$ \\
\hline SC6 & .877 & 1.162 & .108 & $10.779^{* *}$ \\
\hline SC7 & .794 & 1.010 & .104 & $9.670^{* *}$ \\
\hline SC8 & .626 & .631 & .084 & $7.498^{* *}$ \\
\hline Model fits: & \multicolumn{4}{|c|}{$\begin{array}{l}C M I N=274.52 ; D F=145 ; C M I N / D F=1.893 ; P \text {-value }=.021 ; G F I=.876 ; \text { PClose }=.060 ; \\
T L I=.964 ; C F I=.927 ; R M S E A=.047 ; R M R=.038\end{array}$} \\
\hline
\end{tabular}

According to table 4, the Construct Reliability (CR) of the variables relational governance recorded a figure of 0.995 , the level of information recorded 0.905 , quality of information recorded 0.927 and the supply chain performance recorded 0.928 . All the figures recorded by the variables under the construct reliability were at least 0.7. Under the Convergent Reliability (AVE) relational governance recorded 0.658 , the level of information 
recorded 0.615 , the quality of information recorded 0.717 and the supply chain performance recorded 0.618 . All the figures indicated on the table 3 by the variables under the convergent reliability were at least 0.5 . The square root of the Convergent Reliability $(\sqrt{\mathrm{AVE}})$ recorded by the various variables ( $\mathrm{ReG}$ is 0.811 , LoI is 0.784 , QoI is $0.847, \mathrm{SCP}$ is 0.786 ) all shown in the Table 3 . The Table 3 indicates the least ( $\mathrm{AVE}$ ) recorded $\underline{\mathbf{0 . 7 8 4}}$ and the highest correlation figure recorded 0.631 . The least $(\sqrt{ } \mathrm{AVE})$ recorded is larger or greater than the highest correlation figure. A discriminant validity is attained.

As presented by Bamfo et al. (2018), the discriminant validity for the constructs were assessed by comparing the squared-root of the AVEs ( $\sqrt{ }$ AVEs) with the inter-correlation scores. To conclude there was discriminant validity, the $\sqrt{ }$ AVEs are expected to be greater than the respective inter-correlation scores.

Table 3: Discriminant Validity

\begin{tabular}{lllllll}
\hline Variables & CR & AVE & ReG & LoI & QoI & SCP \\
\hline ReG & 0.955 & 0.658 & $\underline{\mathbf{0 . 8 1 1}}^{* *}$ & & & \\
LoI & 0.905 & 0.615 & $0.474^{* *}$ & $\underline{\mathbf{0 . 7 8 4}}^{* *}$ & & \\
QoI & 0.927 & 0.717 & $0.631^{* *}$ & $0.492^{* *}$ & $\underline{\mathbf{0 . 8 4 7}}^{* *}$ & $\mathbf{0 . 7 8 6}$ \\
SCP & 0.928 & 0.618 & $0.610^{* *}$ & $0.571^{* *}$ &
\end{tabular}

** Sig. at $1 \%$

$\sqrt{ } A V E$ are bold and underlined

\subsection{Results and Discussions}

Table 4 presented the various path, their standardized and unstandardized estimates, their Standard Errors and their Critical Ration. Figure 4 also presents the diagrammatic presentation of path analysis performed by using Structural Equation Modelling. The study controlled for two firm specific characteristics (age and size), to determine if they had any effect on the outcome of the study. Results presented in Table 4 indicates that, although both age and size (measured by the number of employees) had a positive effect on supply chain performance, only age had a significant effect $\left(\beta=0.271^{* *}\right)$. In other words, the supply chain performance of the manufacturing firms studied, varied across age group, with older firms having higher performance.

There is direct effect of relational governance on supply chain performance of manufacturing firms in Ghana. Results presented indicates that relational governance had a significant positive effect on supply chain performance of manufacturing firms $\left(\beta=0.594^{* *}\right)$. This implies that, $100 \%$ improvement in relational governance activities such as working together with partner to forestall problems, negotiating adjustments in prices, adapting to partner's needs, etc., positively enhanced supply chain performance by $59.4 \%$, and the vice versa. David (2005) indicated that the performances of firms improves when relational norms of exchange of information and solidarity are fit to culturally founded norm expectations across culturally diverse relationships simultaneously. Singh (2016) indicated that relational governance which facilitates joint decision making is theorized as playing a central role between the resources and the outcome measures.

The mediating role of level of information sharing in the relationship between relational governance and supply chain performance. With this objective, it was expected that the relationship between relational governance and supply chain performance; the relationship between relational governance and level of information sharing; and the relationship between the level of information sharing and supply chain performance, were determine, to calculate for the indirect effect of level of information sharing. From the Table 4, we realized that relational governance had a significant positive effect on the level of information sharing $\left(\beta=0.460^{* *}\right)$. This means that, increasing relational governance by $100 \%$ leads to an increase in level of information sharing among supply chain members by $46 \%$, and vice versa. Similarly, level of information sharing also had a positive significant effect on supply chain performance of the manufacturing firms $\left(\beta=0.743^{* *}\right)$. The coefficient of 0.743 indicates that, a rise in the level of information sharing by $100 \%$, will cause a rise in supply chain performance by $74 \%$, and vice versa. From Table 4, we realized that relational governance has a direct effect on supply chain performance $\left(\beta=0.594^{* *}\right)$. This notwithstanding, Table 5 indicates that level of information sharing had a significant mediating effect $\left(\beta=0.342^{* *}\right)$. This implies that, the effect of relational governance on supply chain performance, is not only direct, but also explained through the mediating role of the level of information shared among supply chain members. Hewett (2001) indicated that relational governance can also lead to a reduction in production and transaction costs by converting strengthened partnerships into stable and loyal strategic alliances. When relational control exist, there will be an establishment of trust among the partners, there is a high flow of relevant information among the firms. Fawcett (2007) indicated that the two dimensions of Information sharing namely the comparability and the readiness which were both discovered to control supply chain performance. And also sharing of information is said to improve supply chain agility and visibility, and therefore positively impacts supply chain stability which is indicated by (Zailani 2006). Rashed (2010) presented that they have utilized the impact of both information and knowledge sharing on supplier's operational performance.

The mediating role of quality of information in the relationship between relational governance and supply chain performance. With this objective too, it was expected that the relationship between relational governance 
and supply chain performance; the relationship between relational governance and quality of information; and the relationship between the quality of information and supply chain performance, were determine, to calculate for the indirect effect of quality of information. From the Table 4, we realized that relational governance had a significant positive effect on the quality of information shared among supply chain members $\left(\beta=0.374^{* *}\right)$. This means that, increasing relational governance by $100 \%$ leads to an increase in quality of information shared among supply chain members by $37.4 \%$, and vice versa. Similarly, quality of information also had a positive significant effect on supply chain performance of the manufacturing firms $\left(\beta=0.629^{* *}\right)$. The coefficient of 0.629 indicates that, a rise in the quality of information by $100 \%$, will cause a rise in supply chain performance by $62.9 \%$, and vice versa. From Table 4, we realized that relational governance had a direct positive effect on supply chain performance $\left(\beta=0.594^{* *}\right)$. However, Table 5 also indicates that quality of information had a significant mediating effect $\left(\beta=0.235^{* *}\right)$. This implies that, the effect of relational governance on supply chain performance, is not only direct, but also explained through the mediating role of the quality of information shared among supply chain members. Relational governance can also lead to a reduction in production and transaction costs by converting strengthened partnerships into stable and loyal strategic alliances (Hewett 2001 ). Weitz (1995) indicated that relational governance in a long term builds trust and commitment among firms, unlike traditional approaches to business relationships that rely heavily on authority and contract to coordinate inter-organizational activities. Zhou et al. (2014) indicated that firms must to link supply chain practices with the quality of information in order to enhance the overall business performance which includes supply chain performance. There has been a confirmation that when quality of information is shared, then better supply chain performance is achieved.

Table 4: Direct Path Estimates

\begin{tabular}{lllll}
\hline Paths & Std. Estimates & Unstd. Estimates & S. E. & C. R. \\
\hline $\mathrm{ReG} \rightarrow$ LoI & .296 & .460 & .134 & $3.433^{* *}$ \\
$\mathrm{ReG} \rightarrow$ QoI & .244 & .374 & .111 & $3.369^{* *}$ \\
$\mathrm{ReG} \rightarrow$ SCP & .222 & .594 & .119 & $4.992^{* *}$ \\
$\mathrm{LoI} \rightarrow$ SCP & .452 & .743 & .136 & $5.466^{* *}$ \\
QoI $\rightarrow$ SCP & .518 & .629 & .141 & $4.461^{* *}$ \\
$\mathrm{Age} \rightarrow$ SCP & .202 & .271 & .079 & $3.441^{* *}$ \\
Size $\rightarrow$ SCP & .031 & .033 & .049 & 0.673 \\
\hline
\end{tabular}

** Sig at $1 \%$

Table 5: Mediating Effect

\begin{tabular}{|c|c|c|c|c|c|}
\hline \multirow{2}{*}{ Indirect Path } & \multicolumn{2}{|c|}{ Indirect Effect } & $\begin{array}{l}\text { Bootstrap Bias-Corrected } \\
\text { Confidence Interval at } 95 \%\end{array}$ & \multirow{2}{*}{ Sig. } & \multirow{2}{*}{$\begin{array}{l}\text { Sobel's } \\
\text { Test }\end{array}$} \\
\hline & $\begin{array}{l}\text { Std. } \\
\text { Estimate }\end{array}$ & $\begin{array}{l}\text { UnStd. } \\
\text { Estimate }\end{array}$ & Lower Bound Upper Bound & & \\
\hline $\mathrm{ReG} \rightarrow \mathrm{LoI} \rightarrow \mathrm{SCP}$ & .134 & .342 & .166 & .003 & $2.907^{* *}$ \\
\hline $\mathrm{ReG} \rightarrow \mathrm{QoI} \rightarrow \mathrm{SCP}$ & .126 & .235 & .145 & .011 & $2.688^{* *}$ \\
\hline
\end{tabular}

$* *$ Sig at $1 \%$ 


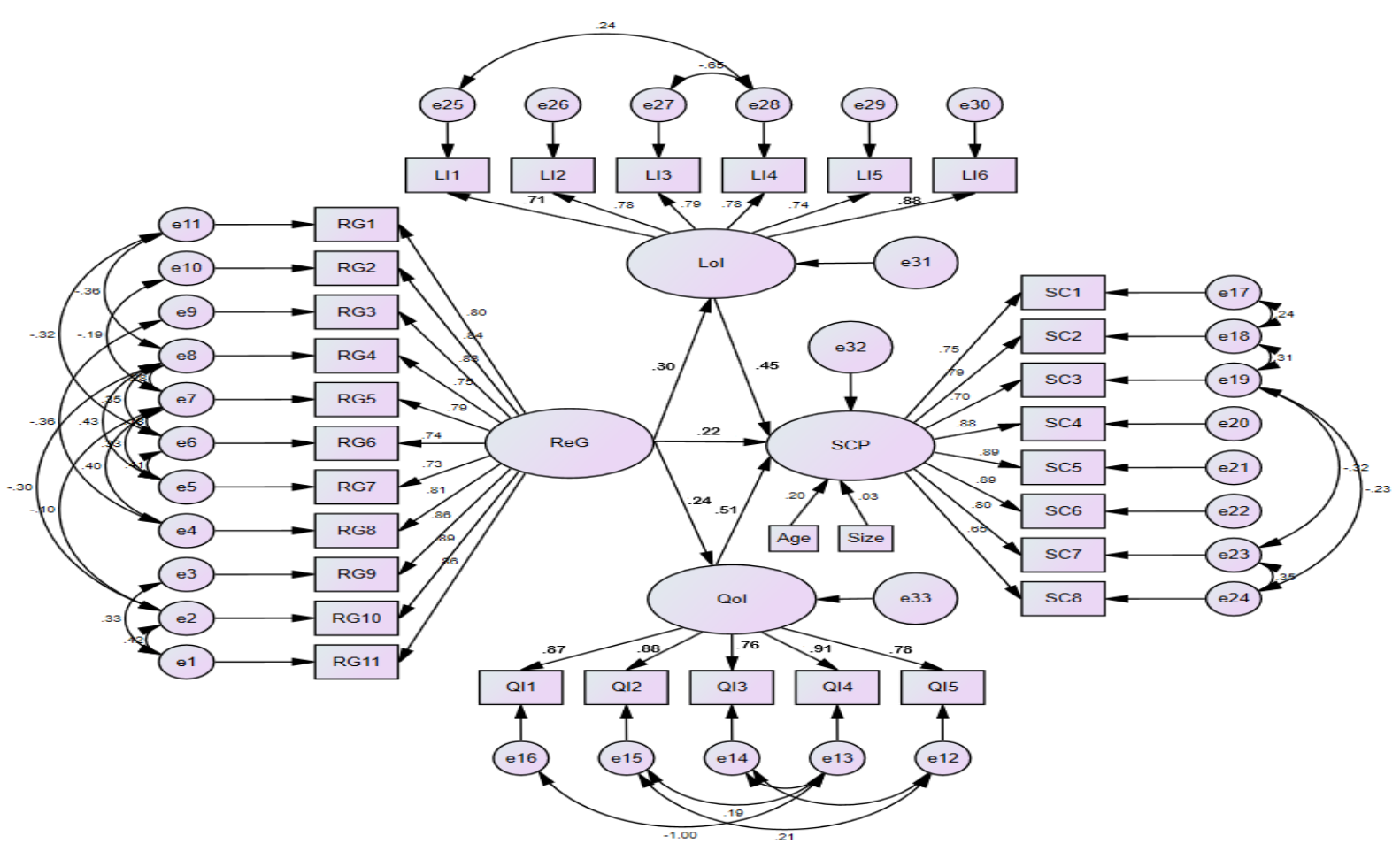

Figure 1: Diagrammatic Presentation of Path Analysis

\subsection{Conclusions}

Based on the SEM theory, this study observes support for a hypothesized model that link relational governance to supply chain performance directly and indirectly (through practices such as level of information sharing and quality of information). The result derived supports that both level of information and quality of information mediate the influence of relational governance on supply chain performance of the manufacturing firms.

\subsection{Theoretical and Practical implication}

This study provides hard evidence showing that higher level of information sharing and quality of information can lead to enhance the influence relational governance has on the supply chain performance of manufacturing firms. The results through this study indicate that trading partners of the manufacturing firms must fully inform the firms about any issue that might affect the firms and also the firms must effectively exchange information with trading partners in order to establish the firms' business planning and also information exchanged between the manufacturing firms and their partners must be time bound. All information regarding their transactions must be effectively communicated and be on time. The result also shows there must be accuracy in the information exchange between the manufacturing firms and their partners. This helps the manufacturing firm to pay maximum attention to their forms of communication and the necessity in keeping a pleasant relationship among their partners.

\subsection{Research Limitation and Future Studies}

There are some limitation observed in this study which can be improved in this research for future research. First and foremost, there is a likelihood that some variables are omitted in this study. Perhaps, the availability of the omitted variables could better the predictions and understanding of the influence the mediating role of both the level of information sharing and the quality of information on the relationship between relational governance and supply chain performance of the manufacturing firms. Also, time constraint on the part of the manufacturing firms was a major challenge. The future studies on the study from the viewpoint of the stakeholders can consider variables which were not addressed in this research. The introduction of the new variables may have some influence on the outcome of the research in the future.

\section{REFERENCES}

Al-Shboul, M. A. R., Barber, K. D., Garza-Reyes. J. A., Kumar. V., Reza Abdi, M. (2014). “The effect of supply chain management practices on supply chain and manufacturing firms' performance." Journal of Manufacturing Technology Management 28(5): 577-609

Banomyong, R. A. S., N. (2011). "Developing a supply chain performance tool for SME in Thailand." Supply Chain Management: An International Journal 16(1): 20-31.

Bamfo, B. A., Dogbe, C. S. K. \& Mingle, H. (2018). “Abusive customer behaviour and frontline employee turnover 
intentions in the banking industry: The mediating role of employee satisfaction," Cogent Business \& Management, 5:1, 1522753

Barney, J.B. and Hansem, M.H. (1994). Trustworthiness as a source of competitive advantage. Strategic Management Journal, 15, 175-90, Special Issue: Competitive Organizational Behavior.

Blos, M. F., Quaddus, M., Wee, H.W. and Watanabe, K. (2009). "Supply chain risk management (SCRM): a case study on the automotive and electronic industries in Brazil." Supply Chain Management: An International Journal 14 (4): 247-252.

Bradach, J. L., \& Eccles, R. G. (1989). "Price, authority, and trust: From ideal types to plural forms." Annual Review of Sociology 15(97-118).

Cannon, J. P., Doney, P.M., Mullen, M.R. and Petersen, K.J. (2010). "Building long-term orientation in buyersupplier relationships: the moderating role of culture." Journal of Operations Management 28. (6): 506-510.

Cannon, J. P. a. P., W.D. Jr (1999). "Buyer-seller relationships in business markets." Journal of Marketing Research 36(4): 439-460.

Cao, Z., \& Lumineau, F. (2015). "Revisiting the interplay between relational and contractual governance: A qualitative and meta-analytic investigation." Journal of Operations Management 33-34: 15-42.

Carvalho, H., Azevedo, S.G. and Cruz-Machado, V. (2014). "Supply chain management resilience: A theory building approach." International Journal of Supply Chain and Operations Resilience 1(1): 3-27.

Chen, I. J. a. P., A. (2004). "Towards a theory of supply chain management: the constructs and measurements." Journal of Operations Management 22(2): 119-150.

Cheng, J. H., Chen, M. C., \& Huang, C. M. (2014). Assessing inter-organizational innovation performance through relational governance and dynamic capabilities in supply chains. Supply Chain Management: An International Journal. 19(2), 173-186

Choi, S. B., Min, H., Joo, H.Y. and Choi, H.B. (2016). "Assessing the impact of green supply chain practices on firm performance in the Korean manufacturing industry." International Journal of Logistics Research and Applications: A Leading Journal of Supply Chain Management 20(2): 129-145.

Claro, D. P., Hagelaar, G., \& Omta, O. (2003). "The determinants of relational governance and performance: How to manage business relationships." Industrial Marketing Management, 32(8): 703-716. .

Cullen, J. B., Johnson, J. L., \& Sakano, T. (2000). "Success through commitment and trust: The soft side of strategic alliance management." Journal of World Business 35(3): 223-240.

Dani, S. a. D., A. (2010). "Fragile food supply chains: reacting to risks." International Journal of Logistics Research and Applications:A Leading Journal of Supply Chain Management 13(5): 395-410.

David, A., \& Matthew, B., M., (2005). "The performance implications of strategic fit of relational norm governance strategies in global supply chain relationships." Journal of International Business Studies volume 36: 254-269.

Dolci, P. C., Maçada, A. C. G., \& Paiva, E. L. (2017). Models for understanding the influence of supply chain governance on supply chain performance. Supply Chain Management: An International Journal. 22(5), 421441.

Ellinger, A. (2000). "Improving marketing/logistics cross-functional collaboration in the supply chain." Industrial Marketing Management 29: 85-96.

Fawcett, S. E., Osterhaus, P., Magnan, G.M., Brau, J.C., \& McCarter, M.W. (2007). "Information sharing and supply chain performance: the role of connectivity and willingness" Supply Chain Management: An International Journal 12(5): 358-368.

Ferguson, R. J., Paulin, M., \& Bergeron, J. (2005). Contractual governance, relational governance, and the performance of interfirm service exchanges: The influence of boundary-spanner closeness. Journal of the Academy of Marketing Science, 33(2), 217-234.

Foerstl, K., Reuter, C., Hartmann, E. and Blome, C. (2010). "Managing supplier sustainability risks in a dynamically changing environment - sustainable supplier management in the chemical industry." Journal of Purchasing and Supply Management 16(2): 118-130.

Gil, N. (2009). "Developing Cooperative Project Client-Supplier Relationships: How Much to Expect from Relational Contracts?" California Management Review 51(2): 144-169.

Griffith, D. A., \& Myers, M. B. (2005). "The performance implications of strategic fit of relational norm governance strategies in global supply chain relationships." Journal of International Business Studies, 36: 254-269.

Heide, J. B. (1994). "Plural governance in industrial purchasing." Journal of Marketing 67: 18-29.

Heide, J. B., \& John, G. (1988). The role of dependence balancing in safeguarding transaction-specific assets in conventional channels. Journal of marketing, 52(1), 20-35.

Hewett, K., \& Bearden, W. O (2001). "Dependence, trust, and relational behavior on the part of foreign subsidiary marketing operations: Implications for managing global marketing operations " Journal of Marketing 65(4): 51-66. 
Hewett, K., \& Bearden, W. O. (2001). "Dependence, trust, and relational behavior on the part of foreign subsidiary marketing operations: Implications for managing global marketing operations." Journal of Marketing 65(4): 51-66.

Igarashi, M., de Boer, L. and Fet, A.M. (2013). "What is required for greener supplier selection? A literature review and conceptual model development." Journal of Purchasing and Supply Management: Journal of Purchasing and Supply Management 19(4): 247-263.

Inemek, A. a. T., O. (2009). "Global supplier selection strategies and implications for supplier performance: Turkish suppliers' perception." International Journal of Logistics Research and Applications: A Leading Journal of Supply Chain Management 12(5): 381-406.

Kaynak, H. (2003). "The relationship between total quality management practices and their effects on firm performance." Journal of Operations Management 21(4): 405-435.

Kumar, V., Holt, D., Ghobadian, A. and Garza-Reyes, J.A. (2015). "Developing green supply chain management taxonomy based decision support systems." International Journal of Production Research 53(21): 6372-6389.

Li, G., Lin, Y., Wang, S., \& Yan, H. (2006). "Enhancing agility by timely sharing of supply information." Supply Chain Management: An International Journal 11(5): 425-435.

Li, S., Subba Rao, S., Ragu-Nathan, T.S., \& Ragu-Nathan, B. (2005). "Development and validation of a measurement instrument for studying supply chain management practices." Journal of Operations Management 23(6): 618-641.

Li, S. a. L., B. (2006). "Accessing information sharing and information quality in supply chain management." Decision Support Systems 42(3): 1641-1656.

Li, S. a. L., B. (2006). "Accessing information sharing and information quality in supply chain management." Decision Support Systems 42(3): 1641-1656.

Macneil, I. R. (1980). Power, contract, and the economic model. Journal of Economic Issues, 14(4), 909-923.

Moberg, C., Cutler, B., Gross, A. and Speh, T (2002). "Identifying antecedents of information exchange within supply chains." International Journal of Physical Distribution \& Logistics Management 32(9): 755-770.

Moorman, C., Zaltman, G. and Deshpande, R. (1992). "Relationships between providers and users of marketing research: the dynamics of trust within and between organisations." Journal of Marketing Research 29(3): 314329.

Morgan, R. a. H., S (1994). "The commitment-trust theory of relationship marketing." Journal of Marketing 58(3): 20-38.

Ness, H. (2009). "Governance, negotiations, and alliance dynamics: Explaining the evolution of relational practice." Journal of Management Studies 46(3): 451-480.

Papalexi, M., Bamford, D. and Dehe, B. (2016). "A case study of kanban implementation within the pharmaceutical supply chain." International Journal of Logistics Research and Applications: A Leading Journal of Supply Chain Management 19(4): 239-255.

Paulin, M., Perrien, J., Ferguson, R.J. and Alvarez-Salazar, A.M (1999). "External effectiveness of service management: a study of business-to-business relationships in Mexico, Canada and the USA." International Journal of Service Industry Management 10(5): 409-429.

Pomegbe, W. W. K., Li, W., Dogbe, C. S. K., Sarsah, S. A. \& Owusua, E. A. (2019). Firm Performance and Competitive Advantage: The role of Green Supply Chain Management Practices. Journal of Business Management and Economics, 7(8), 10-22. DOI: https://doi.org/10.15520/jbme.v7i08.2671

Poppo, L., \& Zenger, T. (2002). "Do Formal Contracs and Relational Governance Function as Substitutes or Complements?" Strategic Management Journal 23: 707-725.

Poppo, L., \& Zenger, T. (2002). "Do formal contracts and relational governance function as substitutes or complements." Strategic Management Journal 23: 707-725.

Rashed, C. A. A., Azeem, A., Halim, Z. (2010). "Effect of Information and Knowledge Sharing on Supply Chain Performance: A Survey Based Approach." Journal of Operations and Supply Chain Management 3(2): 6177.

Reyes, P., Raisinghani, M.S. and Singh, M. (2002). "Global supply chain management in the telecommunications industry: the role of information technology in integration of supply chain entities." Journal of Global Information Technology Management 5(2): 46-67.

Rosenzweig, E. G., Roth, A.V. and Dean, J.W. Jr, (2003). "The influence of an integration strategy on competitive capabilities and business performance: an exploratory study ofconsumer products manufacturers." Journal of Operations Management 21(4): 437-456.

Saad, M., Jones, M. and James, P. (2002). "A review of the progress towards the adoption of supply chain management (SCM) relationships in construction." European Journal of Purchasing and Supply Management 8(3): 173-183.

Singh, A. T., J., T., C., (2016). "Enhancing supply chain outcomes through Information Technology and Trust." Computers in Human Behavior 54: 290-300. 
Stevens, G. C. (1990). "Successful supply chain management." Managenent Decision 28(8): 25-30.

Vanderhaeghe, A. a. d. T., S. (2003). "How to fail at flexibility." Supply Chain Forum: An International Journal 4(1): 64-67.

Weitz, B. A., \& Jap, S. D (1995). "Relationship marketing and distribution channels." Journal of the Academy of Marketing Science 23(4): 305-320.

Ying-Pin Yeh (2016). "Critical influence of relational governance on relationship value in strategic supply management." European Business Review 28(2): 137-154.

Zailani, S., \& Rajagopal, P. (2006). The effects of Information Quality on Supply Chain Performance: New Evidence from Malaysia. Information Quality Management. In Latif Al- Hakim (Ed.), IGI Global: $275-229$.

Zhang, X., \& Aramyan, L. H. (2009). A conceptual framework for supply chain governance. China Agricultural Economic Review. 1(2), 136-154.

Zhao, X., Xie, J., \& Leung, J. (2002). "The impact of forecasting model selection on the value of information sharing in a supply chain" European Journal of Operation Research: 321-344.

Zhao, Y. (2002). The Impact of Information Sharing on Supply Chain Performance. Industrial Engineering and Management Sciences. Evanston, Illinois, Northwestern University. Ph.D.

Zimmermann, F. a. F., K. (2014). "A meta-analysis of the 'purchasing and supply management practiceperformance link " Journal of Supply Chain Management 50(3): 37-54. 